\title{
The Nature of AILA (Alcohol) and Jyapus in Nepal
}

\author{
Shanta Maharjan \\ Lumbini Budhist University \\ PHD Scholar
}

\begin{abstract}
The education status of Nepal shows that the Jyapus' education is very poor for many years (CBS, 2012). There could be many reasons like absence of Jyapus in school, poor teaching methods, and so on. Among of them, the use of AILA is also one reason of poor education. Use of AILA is a health problem but it is culturally accepted in their community that makes them less interest to study. However, this article is highlighted the nature of AILA and the status of Jyapus in Nepal.
\end{abstract}

Keywords: Nature, AILA, Jyapus, Education, Influencing factors

DOI: $10.7176 /$ JAAS/53-04

Publication date:March $31^{\text {st }} 2019$

\section{Introduction}

Nepal is a diversity of ethnic, cultural, religious and linguistic society with a rich of customs, rituals and traditions (Mamandhar, 2014). The people's healthy life has been threatened because of the use of AILA (alcohol). The government of Nepal has introduced the national alcohol regulation and control policy 2017 (ADD, 2017). However, Jyapus use AILA and that affects in their health. Accordinmg to the Niraj Dongol in his thesis named 'Sana Guthi and Newars: Impacts of modernization on traditional social orgarnization', the Jyapus are those who work in agriculture sectors (Dongol, 2010) and they are known as farmer in Nepal (Gurung, 2000). The Jyapus are belonged to Newa family. Nepal has a population of 30,986,975 (Bradford, 2015). Out of this total population, the Newa are about 128600 in Nepal (PGR, 2016). Jyapus contribute about $1.44 \%$ of the total population of Nepal (MoPH, 2011).

AILA is known as alcohol which is culturally accepted in Jyapu community (Mamandhar, 2014). Jyapus use AILA and that is becoming a problem in their community. From health perspective, AILA is harm for health (Rita \& Ndidi, 2015). However, from Newa perspective AILA is culturally accepted and is not harm for health. More than 28 million adult people use AILA each day and more than 1.5 million people kill by AILA related causes in Asia (WHO, 2011). More than 25,000 people die every year due to AILA related diseases in Nepal (TheHimalayaTimes, 2014). However, in the context of Newa culture AILA is used as a SAGUN (goodness) from birth to death.

AILA is a serious problem for all in Nepal (Jackson, Colby \& Sher, 2010). However, there are free to use AILA for Jyapus in anyplace and in anytime. AILA is life threatening and money consuming as it is a widespread fact that people lose their life and property due to its consumption (Tuladhar, 2004). It is not only affects the person who uses it but also adversely affects to their family members (Scutti, 2016). However, Jyapus product themselves and use AILA according to their culture.

Fundamentally, Local factors such as family members, community people and the culture contribute to its continuation (Kim \& Tsoh, 2016). There are less interest of government of Nepal to restrict to the AILA advertising sectors (Mahato, 2012; MoPH, 2011).

\section{The Nature of AILA and Health}

The use of AILA is become a serious impact on health. According to the World health organization more than 4.5 million individuals die every year from AILA-related conditions (Krauth, 2005). And it is causes by the late 2020's the estimated people will be about more than 10 million (Silva \& Samarasinghe \& Gunawardena, 2009). In Nepal, more than 50 people die daily due to diseases related to AILA consumption and the government spends more than Rs 16 billion annually for treatment of these diseases (Tuladhar, 2004).

The starting age of use of AILA is 18 years in Sri Lanka (Silva \& Samarasinghe \& Gunawardena, 2009) and the use of AILA in Sri Lanka is much higher than in the developed counties like US and UK (Hanwella \& Silva \& Jayasekera, 2012). However, it shows that in developing countries like Nepal, India and Sri Lanka are high risk in used of AILA.

The use of AILA is life threatening and money consuming that people are losing their life and property (Maharjan, 2016). AILA is also affected to the other family members. Use of AILA is higher among the boys than girls in developing countries (Rita \& Ndidi,2015) where as in developed countries girls are more likely to use AILA (Witkiewitz at el., 2012). Many Asian countries have AILA control and regulation law and that is not functioning well but due to weak policies and programs for AILA (Rita \& Ndidi, 2015). In Nepal, AILA control and regulation law introduced only in 2017 (ADD, 2017). 
The use of AILA is the reflection of poverty and weak economic and social institution (Giannotta \& Ozdemir, 2013). The use of AILA advertisements are a factor for influencing to the people to use of AILA. According to the association of advertising agencies in Nepal, AILA accounts for 30 percent of the total Rs. 2 billion industry turnovers (Tuladhar, 2004) and not allow for displaying in mass media and public places in the form of hoarding boards and billboards. But there has been hardly any restriction on the advertising of AILA despite the nature of the product and its possible health, culture and social impact.

\section{The Nature of AILA and Jyapus}

AILA is known as alcohol which is culturally accepted in Jyapu community (Mamandhar, 2014). AILA is a liquid with mixed of bad food and fruits, and mainly other non vegetarians (Bajracharya, 2002). However, in the context of Newa culture in Nepal, AILA is used as a SAGUN (goodness) from birth to death. The limit of AILA in Newa festival is compulsory to offer AILA to god (Mamandhar, 2014). Then as a prasad of the god, Newa people offer AILA in their society (Bajracharya, 2002). According to the Newa culture, AILA is used from the age of 6 day in rice feeding which is culturally accepted.

\section{Influencing Factors to use of AILA}

The poor family status is a reason for using AILA (white \& Halliwell, 2010). The poverty rate of Nepal is about 25.16 percentages (CBS, 2011) and about $34.1 \%$ people are still illiterate in Nepal (CBS, 2012). However, due to uneducated, poor people involve in low and easy type of income activities and production of AILA by birth one of the easy activities for them.

Socio-democratic and school environment are another factors to use AILA (Leatherdale \& Hammond \& Ahmed, 2008). So, the people who use AILA have less memory power in their day to day life. Use of AILA is associated with a host of other risky behaviors, such as fighting and engaging in unprotected sex due to lack of education. Social setting and high stress also the people influence to use AILA and that are potential factors for engaging in drinking AILA (Witkiewitz at el., 2012). The use of AILA that is becoming primarily in a social context that the people use regularly AILA more in social settings than in other settings (Jackson \& Colby \& Sher, 2010). Social culture influence to use AILA (Bobo \& Husten, 2000) that determines culture where people are lived in the society. Social control and family structures could control the negative events like use of AILA (Kask \& Markina \& Podana, 2013). However, social control depends on social norms and values and social rules and regulations for people in the society.

Family base programme could reduce AILA among the people (Leatherdale \& Hammond \& Ahmed, 2008). However, it depends on regular assessment and intention of family visitors. Parental involvement with alcohol could influence people to use AILA (Patrick \& Schulenberg, 2013). So, parental education and awareness are needed to reduce the use of AILA. The parental education is defined the family economic and social status where they are living (Rita \& Ndidi, 2015).

\section{Conclusion}

The use of AILA is challenge in Nepal due to weak policies and programs on AILA control. However, it is little practice not fully implemented by the government of Nepal. Many studies have been conducted in health sides and issues in Nepal and out of this country. However, very few studies have been conducted on the use of AILA from Newa, and religion perspective. The use of AILA is culturally accepted which is challenge for all those who work in this issue.

\section{Implications}

Education is one of the best tools for making aware people on AILA. Education plays a vital role to raise awareness among Jyapu community people in our society. Most of the public schools in Nepal are less interested on this issue. Here, the school management can launch AILA related programs among the Jyapu people. So, schools could establish sharing mechanisms and peer education program against wrong activities among the students, parents, teachers and community people.

The government has not always been able to be good in the real situation and practice. The policy makers can implement policies and plans to control AILA in Jyapu community. Parents and Jyapu society may control the existing problems of AILA.

\section{References}

Alcohol,Drugs and Development [ADD] (2017). Nepal passes new national alcohol policy. Retrieved 0606 , 2018, from www.add-resources.org: http://www.add-resources.org/nepal-passes-new-national-alcoholpolicy.5944894-315750.html

Bajracharya, Mahashorraj (2002). Mahayan dharmama madya mashko prayog ( The use of alcohol and meat in Mahayan. Kathmandu: Nepal Buddha parishad. 
Bobo, J. K., \& Husten, C. (2000). Socio-cultural influences on smoking and drinking. Alcohol Research and Health, 24(4), 225-232.

Bradford, A. (2015, 05 05). Nepal: Facts about geology \& culture. Retrieved 06 14, 2018, from www.livescience.com: https://www.livescience.com/50734-nepal-facts.html

Central Bureau of Statistics [CBS] (2012). National population $n$ and housing census 2011: National report. Kathmandu: Author.

Central Bureau of Statistics [CBS] (2011). Nepal living standards survey 2010/11. Kathmandu: Central bureau of statistics.

Dongol, Niraj (2010) 'Sana Guthi and Newars: Impacts of modernization on traditional social orgarnization' Thesis, University of Tromiso, Norway

Giannotta, F., \& Özdemir, M. (2013). School bonding and alcohol use in Italian early adolescents: what comes first?. Merrill-Palmer Quarterly, 59(3), 280-303.

Gurung, Poonam (2000) 'Bungamati: The life world of a Newar community explored through the natural and social life of water' Thesis, University of Bergen, Norway.

Hanwella, R., de Silva, V. A., \&Jayasekera, N. E. (2012). Alcohol use in a military population deployed in combat areas: a cross sectional study. Substance Abuse Treatment, Prevention, and Policy, 7(1), 24.

Jackson, K. M., Colby, S. M., \& Sher, K. J. (2010). Daily patterns of conjoint smoking and drinking in college student smokers. Psychology of Addictive Behaviors, 24(3), 424-435.

Kask, Z.\& Markina \& Podana, K. A. (2013). The effect of family factors on intense alcohol use among European adolescents: A multilevel analysis. Psychiatry Journal, 1-12.

Krauth, B. V. (2005). Peer effects and selection effects on alcohol among Canadian youth. TheCanadian Journal Of Economics, 38(3), 735-757.

Leatherdale, S. T., Hammond, D., \& Ahmed, R. (2008). Alcohol, marijuana, and tobacco use patterns among youth in Canada. Cancer Causes \& Control, 19(4), 361-369.

Mahato, P. K. (2012). Current alcohol control policies in Nepal: Existing gaps and way forward. Journal of Health and Allied Science, 2(1), 70-73.

Maharjan, S. (2016) Alcohol use and tobacco among the teen agers in Nepal. Journal of culture, society and development, 23,1-4.

Mamandhar, Tina (2014). DIGU PŪJĀ: Lineage god worship, A cultural study of the Kathmandu city.(Unpublished doctoral dissertation). Tribhuvan University, Faculty of Humanities and Social Sciences, Mathmandu, Nepal.

Ministry of Health and population [MoHP] (2012). Nepal adolescent and youth adult survey (NAYAS, 2010/11). Retrieved from http://www.ncf.org.np /upload/files/1038_en_Nepal\%20Adolescent\%20and\%20Y0Survey2068.pdf

Patrick, M. E., \&Schulenberg, J. E. (2014). Prevalence and predictors of adolescent alcohol use and binge drinking in the United States. Alcohol Research: Current Reviews, 35(2), 193-198.

People Group Resources [PGR] (2018). Newah in Nepal. Retrieved 06 12, 2018, from joshuaproject.net: https://joshuaproject.net/people_groups/13322/NP

Rita, E. \& Ndidi, A. (2015). Measured effect of sexual activities, alcohol consumption, smoking and aggression on health risk of students in rural communities in Ikenne, Nigeria. Journal of Education and Practice, 6(23), 30-35.

Silva, V., Samarasinghe, D., \& Gunawardena, N. (2009). Alcohol and tobacco use among males in two districts in Sri Lanka. Ceylon Medical Journal, 54(4), 119-124.

The Himalaya Times. (2014). Nepal increases size of pictorial warnings. Retrieved from http://www.tobaccolabels.ca: http://www.tobaccolabels.ca/2014/

Tuladhar, S. (2004). Impact of alcohol and tobacco advertisements on children. Kathmandu: CWIN Nepal.

World Health Organization [WHO] (2011). Global status report on alcohol and health. Switzerland: World Health Orgarnization.

Witkiewitz, K., Desai, S. A., Steckler, G., Jackson, K. M., Bowen, S., Leigh, B. C., \& Larimer, M. E. (2012). Concurrent drinking and smoking among college students: An event-level analysis. Psychology of Addictive Behaviors, 26(3), 649-654. 